\title{
Genomic regions associated with the sex-linked inhibitor of dermal melanin in Silkie chicken
}

\author{
Ming TIAN, Rui HAO, Suyun FANG, Yanqiang WANG, Xiaorong GU, Chungang FENG, Xiaoxiang HU (囚), \\ Ning LI (ه)
}

State Key Laboratory for Agrobiotechnology, China Agricultural University, Beijing 100193, China

\begin{abstract}
A unique characteristic of the Silkie chicken is its fibromelanosis phenotype. The dermal layer of its skin, its connective tissue and shank dermis are hyperpigmented. This dermal hyperpigmentation phenotype is controlled by the sex-linked inhibitor of dermal melanin gene (ID) and the dominant fibromelanosis allele. This study attempted to confirm the genomic region associated with $I D$. By genotyping, $I D$ was found to be closely linked to the region between GGA_rs16127903 and GGA_rs14685542 (8406919 bp) on chromosome Z, which contains ten functional genes. The expression of these genes was characterized in the embryo and 4 days after hatching and it was concluded that MTAP, encoding methylthioadenosinephosphorylase, would be the most likely candidate gene. Finally, target DNA capture and sequence analysis was performed, but no specific SNP(s) was found in the targeted region of the Silkie genome. Further work is necessary to identify the causal $I D$ mutation located on chromosome $\mathrm{Z}$.
\end{abstract}

Keywords sex-linked inhibitor of dermal melanin (Id), Silkie, chromosome Z

\section{Introduction}

The genetics of skin coloration has been studied in many species. For example, in relation to premature grayhair and susceptibility to melanoma in horses [1], the multiple genomic regions implicated in the stripes and spots patterning the coats of domestic cats [2], and the sexlinked yellow color in the Syrian hamster [3]. In chickens, the genetics of plumage [4] and skin [5] has been investigated.

The Silkie chicken (Gallus gallus) is the most studied Chinese breed because it has some interesting anatomical characteristics, such as the crest, walnut comb, blue

Received August 23, 2014; accepted October 23, 2014

Correspondences: huxx@cau.edu.cn,ninglcau@cau.edu.cn earlobes, beard, silkie-feathering trait, feathered legs and polydactyly [6,7]. In particular, the pigmentation of the dermal layer of its skin and shank, and its muscles and connective tissue [8] is a most noteworthy trait, and this breed has served as a model to identify genes that regulate melanocyte migration.

The melanocyte is the main type of dermal cell containing melanin. Melanoblasts are precursors of melanocytes, and during early embryogenesis, they originate from the neural crest [9]. In avian embryos, neural crest cells migrate from the trunk in two waves [10], one via the ventral pathway and the other via the dorsolateral pathway [11]. The melanoblasts of Silkie chickens can also reach the ventral regions of the embryo [12]. This generalized mesodermal pigmentation is a consequence of environmental factors that promote the abnormal migration of melanoblasts and their proliferation and differentiation [13], which in turn may be controlled by the inhibitor of dermal melanin $(I D)$ and fibromelanosis (FM) loci [14].

In Silkie chicken, the hyperpigmentation phenotype is closely related to the sex-linked incompletely dominant inhibitor of dermal melanin $\left(I d / i d^{+}\right)$and the autosomal dominant fibromelanosis $\left(\mathrm{Fm} / \mathrm{fm}^{+}\right)$loci $[14,15]$. Id has an epistatic effect on $F m$, and pigmentation of the shank in the dermis occurs in the presence of $i d^{+}$and $F m$ with $i d^{+}$ causing hyperpigmentation. Linkage analyses showed that $I d$ is located near the end of the long arm of chromosome $\mathrm{Z}$ (chrZ) [16-20]. Dorshorst et al. [21] performed a genomewide single nucleotide polymorphism (SNP)-trait association analysis to identify the genomic regions in which $I D$ and $F M$ are located. They identified SNPs that are associated with $I D$ between 67.1 and $72.3 \mathrm{Mb}$ on chrZ, but this region contains many genes.

Starting in 2009, we have worked to establish crossed chicken breeds to use for the identification of genes that are genetically related to $I D$. Herein we report that $I D$ is associated with a chrZ region that contains ten functional genes, including MTAP, which encodes methylthioadenosine. 


\section{Materials and methods}

\subsection{Ethics statement}

All animal work was conducted according to the Guidelines for the Care and Use of Experimental Animals by the Ministry of Science and Technology of the People's Republic of China (Approval number: 2006-398). Blood samples were collected from the brachial veins of the chickens using a standard venipuncture procedure approved by the Animal Welfare Committee of the China Agricultural University (Permit Number: XK622).

\subsection{Animals}

As a consequence of the epistatic interaction between $I D$ and $F M$, a mapping population of chickens was developed to allow for individual segregation of $I D$ and a clear classification of the shank dermal color phenotypes. Five male Youxima chickens $\left(\mathrm{fm}^{+} / \mathrm{fm}^{+}, i d^{+} / i d^{+}\right)$were mated with 12 female Sanhuang chickens $\left(\mathrm{fm}^{+} / \mathrm{fm}^{+}, \mathrm{Id} / \mathrm{w}\right)$. Two $\mathrm{F}_{1}$ generation males $\left(\mathrm{fm}^{+} / \mathrm{fm}^{+}, \mathrm{Id} / \mathrm{id}^{+}\right)$were chosen. Each was mated with six $\mathrm{F}_{1}$ generation non-half-sib family female chickens $\left(\mathrm{fm}^{+} / \mathrm{fm}^{+}, i d^{+} / w\right)$ (Fig. 1), which allowed for segregation of $I d$ in the $\mathrm{fm}^{+}$background in $342 \mathrm{~F}_{2}$ individuals (both male and female). The trait phenotype of shank color was recorded at 4 and 12 weeks (Fig. 2).

$$
\begin{aligned}
& \mathrm{F}_{0} \quad \text { (Youxi Partridge) } \hat{\delta} \mathrm{fm} \mathrm{fm} / \mathrm{Z}^{i d} \mathrm{Z}^{i d} \times \text { o } \mathrm{fm} \mathrm{fm} / \mathrm{Z}^{I d} \mathrm{~W} \text { (Sanhuang) } \\
& \mathrm{F}_{1} \quad \hat{\mathrm{o}} \mathrm{fm} \mathrm{fm} / \mathrm{Z}^{I d} \mathrm{Z}^{i d} \times \text { 우 } \mathrm{fm} \mathrm{fm} / \mathrm{Z}^{i d} \mathrm{~W} \\
& \mathrm{~F}_{2} \quad \mathrm{fm} \mathrm{fm} / \mathrm{Z}^{I d} \mathrm{Z}^{i d}: \mathrm{fm} \mathrm{fm} / \mathrm{Z}^{i d} \mathrm{Z}^{i d}: \mathrm{fm} \mathrm{fm} / \mathrm{Z}^{i d} \mathrm{~W}: \mathrm{fm} \mathrm{fm} / \mathrm{Z}^{I d} \mathrm{~W} \\
& =1: 1: 1: 1
\end{aligned}
$$

Fig. 1 Founding breeds for the mapping populations
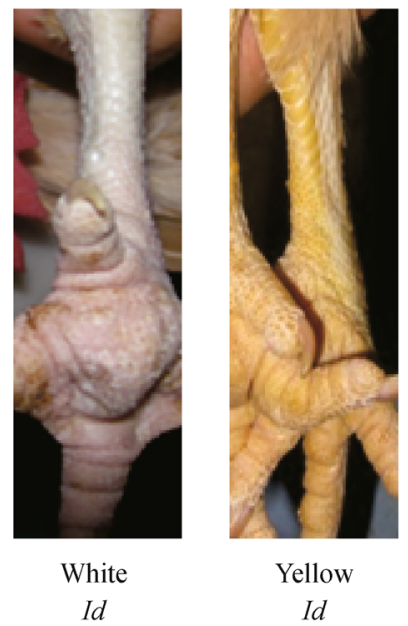
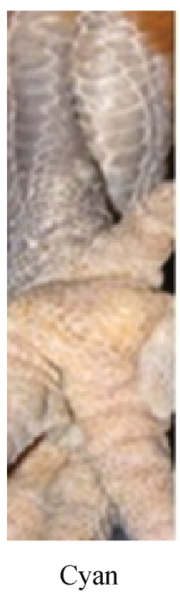

id

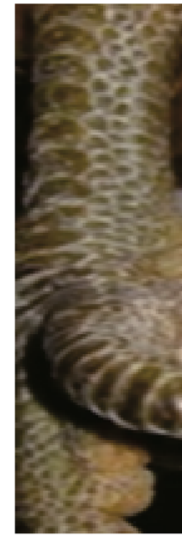

Green $i d^{+}$
Fig. 2 Shank color of crosses ( $\mathrm{F}_{2}$ generation) at 12 weeks
DNA samples from adults of other breeds were obtained from the Poultry Institute of Jiangsu Province, Chinese Academy of Agricultural Sciences, including the ID breeds, Jinhu Silkie and Kuaida Silkie, and the normally pigmented breeds, Anak, White Recessive, Qingyuan ma, Gushi, Wahui, and Cobb Broiler. DNA samples from Silkie and White Leghorn embryos were obtained from the chicken farm at the China Agricultural University.

\subsection{Genotyping}

Fifty-seven SNPs (Appendix A, Table S1, WUGSC2.1/ galGAL3) between 67.1 and $72.3 \mathrm{Mb}$ on chrZ [21] were used for genotyping the $F_{1}$ and $F_{2}$ generations of the crossed population. Each genomic DNA sample was diluted to $30 \mathrm{ng} \cdot \mu \mathrm{L}^{-1}$ in double-distilled water and detected by matrix-assisted laser desorption/ionization time-of-flight mass spectrometry. To construct multilocus linkage maps for ID, CRI-MAP (Version 2.4) (http://www. animalgenome.org/tools/share/crimap/) was used.

\subsection{RNA isolation and real-time quantitative PCR}

Tissue from Silkie and White Leghorn chickens was obtained at embryonic times of $1.5,3,5,8$ and 13 days, and at 4 days after hatching. The embryonic time period represents the gradual change in pigmentation (data not shown). Beginning at embryonic day 5, tissue was collected from the head, heart and hind legs. At least three biological replicates of each breed were collected per time point. Tissue was homogenized with a TissueLyser LT (QIAGEN, Dusseldorf, Germany) in $1 \mathrm{~mL}$ TRIzol reagent (Tiangen, Beijing, China), and RNA was isolated according to the manufacturer's protocol. The real-time quantitative PCR (qPCR) primer sequences are shown in Appendix B-Table S2. Total RNA (1 $\mu \mathrm{g})$ from each sample and M-MLV reverse transcriptase (Promega, Beijing, China) were used to synthesize first-strand cDNA. qPCR was performed using Roche SYBR Green-based real-time qPCR kit reagents, a Roche LightCycler480 instrument, 30 ng cDNA, and 3 pmol of each primer in a total volume of $15 \mu \mathrm{L}$. Thermal cycling parameters used [4] were the default settings, and the PCR products were subjected to melting curve analysis. The Basic Relative Quantification module of LightCycler480 software was used to analyze the data with the associated CT algorithm. Expression for each sample was normalized to glyceraldehyde 3-phosphate dehydrogenase expression. The results for the hyperpigmented and normally pigmented chickens were tested for significance using the unpaired $t$-test. Error bars in Fig. 3 represent the $95 \%$ confidence interval.

\subsection{DNA capture and sequencing data analysis}

DNA samples from 18 Silkie, 21 Jinhu Silkie, 20 Gushi, 
(a)

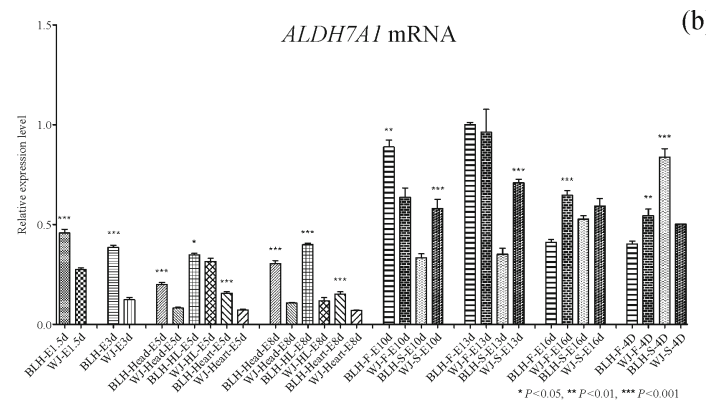

(c)

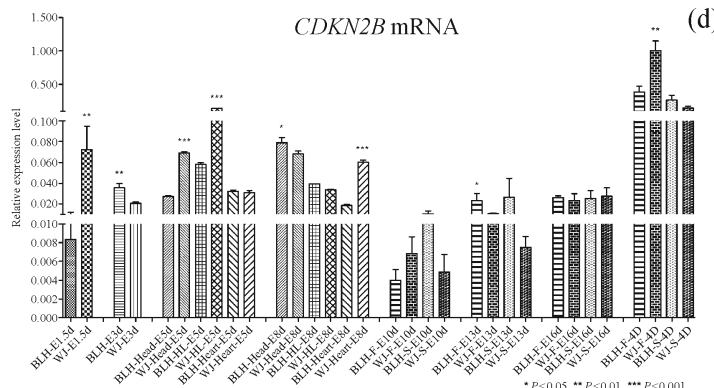

(e)

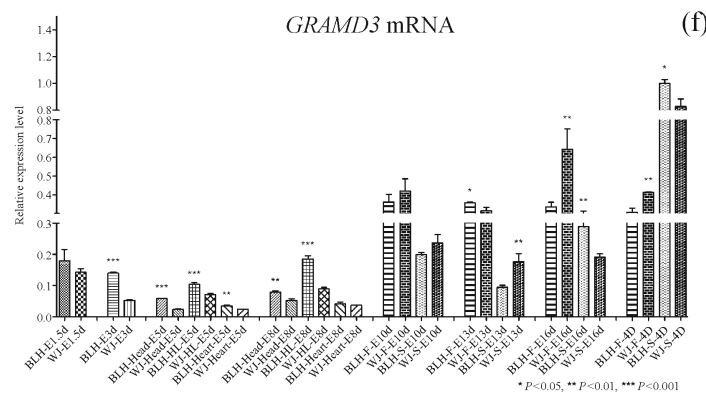

(g)

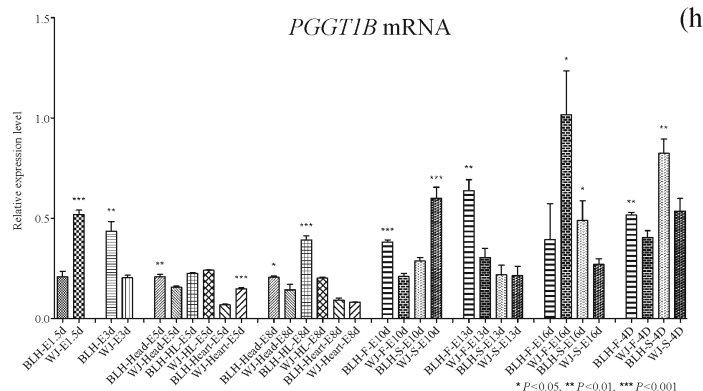

(i)

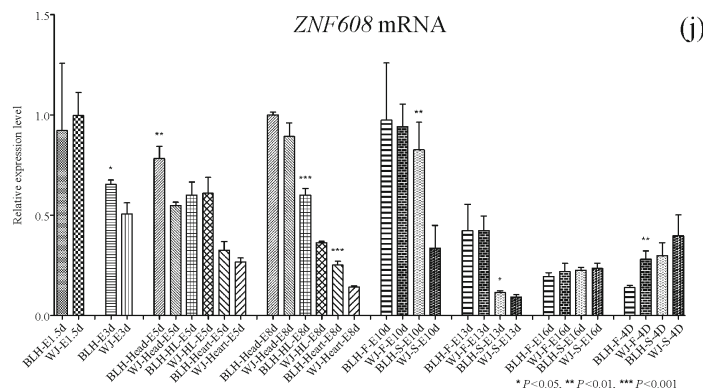

(b)

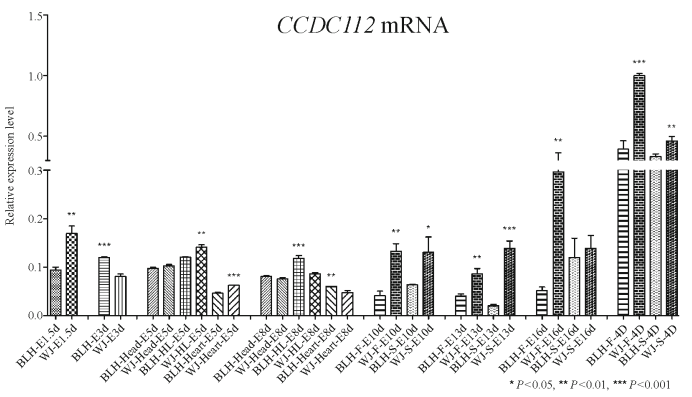

d)

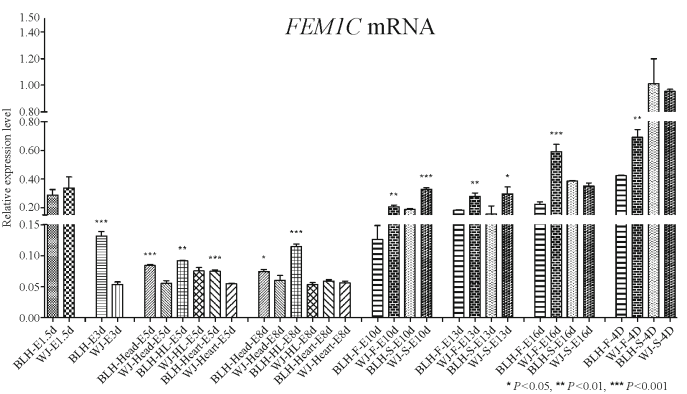

(f)

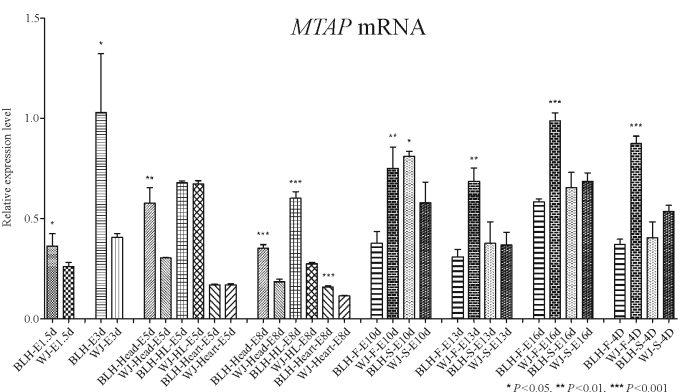

(h)

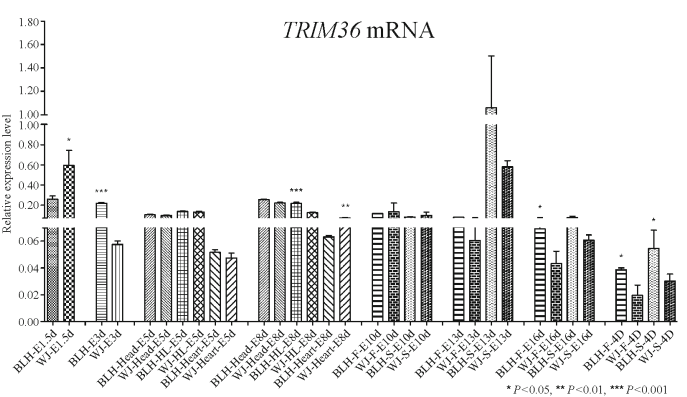

(j)

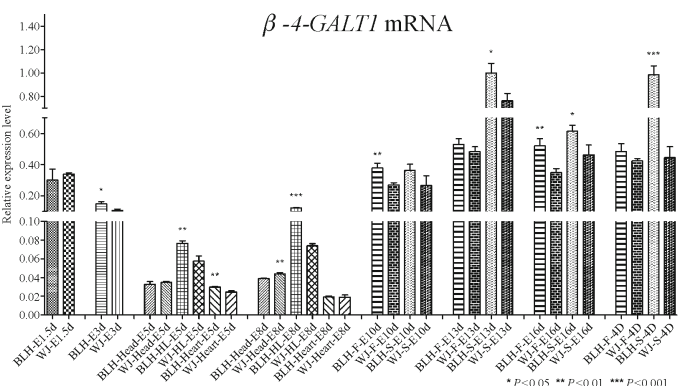

Fig. 3 The results of Q-PCR analysis of the expression of ten target functional genes. (a) $A L D H 7 A 1$ mRNA;(b) CCDC112 mRNA; (c) CDKN2B mRNA; (d) FEMIC mRNA; (e) GRAMD3 mRNA; (f) MTAP mRNA; (g) PGGT1B mRNA; (h) TRIM36 mRNA; (i) ZNF608 mRNA; (j) $\beta$-4-GALT1 mRNA. BLH: White Leghorn. WJ: Silkie. * means $P<0.05$. ** means $P<0.01$. *** means $P<0.001$. These $P$ values are compared between BLH and WJ in each time and tissue. E: embryo. 4D: the 4th day after born. HL: hind-leg. F: shank skin. S: skin. 
21 White Leghorn, 20 Cobb Broiler, 20 Beijing fatty, 20 Wahui, and 22 White Recessive chickens were pooled as breed-specific samples. An Agilent SureSelect DNA Capture array was designed according to the manufacturer's protocol to capture the targeted genomic region on chrZ from 80659505 bp to 82097083 bp as shown in the resequence reference assembly for chrZ [22], and libraries for the targeted genome were collected using the Agilent SureSelect Target Enrichment system. IlluminaHiSeq 2000 (Illumina, San Diego, CA, USA) mate-pair sequencing was performed with these libraries by BerryGenomics Company (Beijing, China). The reads were mapped onto the chicken genome resequence reference assembly.

\section{Results and discussion}

\subsection{The genomic region associated with $I D$}

Dorshorst and colleagues mapped the $I D$ locus to the 67.1$72.3 \mathrm{Mb}$ regions of chrZ [21]. Youxima and Sanhuang chickens were crossed to segregate the $I d$ allele in $342 \mathrm{~F}_{2}$ individuals. The 67.1-72.3 Mb region of chrZ was refined by using 57 markers in the $F_{1}$ and $F_{2}$ generations (markers are according to WUGSC 2.1/galGAL3 (the May 2006 assembly)). By CRI-MAP (2.4) analysis, the multilocus linkage maps was constructed about $I D$ and it found that $I D$ is closely linked with GGA_rs16127903 and GGA_rs14685542. Then we isolated the $1346191 \mathrm{bp}$ region of chrZ that is completely associated with ID according to genotyping. Bellott and colleagues [22] resequenced chrZ of chicken in 2010, and the length of chrZ was increased to 83952565 bp. Therefore, the GGA_rs16127903 to GGA_rs14685542 sequence was used for a BLASTN analysis. In that region, ten functional genes and four " $Z$ amplicons" gene families were found: ADCY10Z, C2Orf3Z, MRPL19Z, RICSZ. Only ten functional genes were examined because these four families contain hundreds of copies of their genes and constitute approximately one-third of the protein-encoding genes on chrZ.

\subsection{Functional gene expression}

The ten functional genes examined were $A L D H 7 A 1$ (aldehyde dehydrogenase 7A1), CCDC112 (coiled-coil domain containing 112), CDKN2B (cyclin-dependent kinase inhibitor 2B), FEMIC (fem-1 homolog c), GRAMD3 (GRAM domain-containing 3), MTAP (methylthioadenosinephosphorylase), PGGT1B (protein geranylgeranyltransferase type I, beta subunit), TRIM36 (tripartite motif-containing 36), ZNF608 (zinc finger protein 608), and $\beta$-4-GALT1 (beta-1,4-galactosyltransferase, polypeptide 1). These genes were all expressed between incubation on day 1.5 through to 4 days after hatching, with no significant different in the expression levels of $\beta$-4-GALT1, TRIM36 and ZNF608 during that time. Before embryonic day 10, the expression of $C D K N 2 B$ and GRAMD3 was significantly greater in Silkie embryos than in White Leghorn embryos. Conversely, during the same time period, the expression of MTAP, ALDH7A1 and FEM1C was significantly greater in White Leghorn embryos than in Silkie embryos. After embryonic day 10, the expression of CCDC112 in the shank of Silkie embryos was significantly greater than in the White Leghorn embryos, but expression of MTAP, ALDH7A1 and $F E M 1 C$ was significantly greater in Silkie embryos than in White Leghorn embryos, which represents a reversal of the expression levels found before day 10 (Fig. $3)$. ALDH7A1 is reported to cause pyridoxine-dependent seizures [23]. GRAMD3 appears in human retinal pigment epithelium [24]. PGGT1B is necessary in skin keratinocytes [25]. TRIM36 may interact with the kinetochore protein CENP-H and delay cell cycle progression [26]. ZNF608 is sequentially related to Drosophila brakeless (Brakeless, also known as Scribbler or Master of thickveins, it is a nuclear protein of unknown function.) [27]. $\beta-4-G A L T 1$ has been suggested to promote stable lamellipodia formation [28], but in our experiment, the results of expression of $\beta-4-G A L T 1$ differed from previous findings, because there was no significant different between Silkie and White Leghorn embryos. Thus it is suggested that $\beta$-4-GALT1 controls stable lamellipodia formation, which would be inconsistent with melanoblast migration in hyperpigmented Silkie chickens [29,30]. Although FEM1 family proteins are conservative in many species, such as humans, mice and zebrafish [31], $F E M 1 C$, is necessary for sex determination only [32], and therefore $F E M 1 C$ was not considered to be a candidate for ID. $C D K N 2 B$ and MTAP are involved in melanin formation or melanoma proliferation [33,34]. MTAP is a housekeeping gene in normal cells, but its expression decreases in melanomacells, thereby promoting melanoma cell proliferation. It is speculated that MTAP might be ID because MTAP activity is related to melanoma proliferation and the expression of MTAP was significantly greater in White Leghorn embryos than in Silkie embryos.

\subsection{Target DNA capture and sequencing}

By target DNA capture and sequencing, many SNPs were found in the target region. Given that $I D$ is inherited in an $\mathrm{X}$-linked recessive fashion, Silkie, Jinhu Silkie and Gushi chickens will be $i d^{+} / i d^{+}$homozygotes, and the White Leghorn, Cobb Broiler, Beijing fatty, Wahui and White Recessive reference breed will be Id/Id homozygotes. Based on the results of the sequence capture study, we identified 53 homozygous SNPs common to the Silkie, Jinhu Silkie and Gushi chickens not found for the reference breeds (Table 1). When consideration of the genotype was discounted, only three candidate SNPs remained:ChrZ_80762601(A/G), ChrZ_80813721(T/C) and ChrZ_81683233(A/T) (Table 2). However, these SNPs are 
Table 1 Sequencing data based on genotype

\begin{tabular}{|c|c|c|c|c|c|c|c|c|}
\hline \multirow[t]{2}{*}{ Chromosome } & \multirow[t]{2}{*}{ Relative locus } & \multicolumn{2}{|c|}{$\begin{array}{l}\text { Silkie-Jinhu and } \\
\text { Silkie-Gushi shared } \\
\text { homozygous SNPs }\end{array}$} & \multicolumn{5}{|c|}{ Genotypes of the reference breeds } \\
\hline & & Ref & Alt & Cobb Broiler & White Leghorn & Beijing fatty & Wahui & White Recessive \\
\hline \multirow{42}{*}{$\operatorname{chrZ}$} & 2321 & $\bar{A}$ & $\mathrm{G}$ & $1 / 1$ & $1 / 1$ & $1 / 1$ & - & $1 / 1$ \\
\hline & 5321 & A & G & $1 / 1$ & $1 / 1$ & - & - & $1 / 1$ \\
\hline & 40214 & A & G & $1 / 1$ & $1 / 1$ & - & $1 / 1$ & $1 / 1$ \\
\hline & 72985 & G & $\mathrm{C}$ & $1 / 1$ & $1 / 1$ & $1 / 1$ & $0 / 1$ & $1 / 1$ \\
\hline & 83822 & G & $\mathrm{C}$ & $1 / 1$ & - & $1 / 1$ & $1 / 1$ & $1 / 1$ \\
\hline & 84032 & $\mathrm{~T}$ & A & $1 / 1$ & $1 / 1$ & $1 / 1$ & - & $1 / 1$ \\
\hline & 88662 & A & $\mathrm{C}$ & $1 / 1$ & $1 / 1$ & $1 / 1$ & $1 / 1$ & $0 / 1$ \\
\hline & 118162 & $\mathrm{~T}$ & $\mathrm{C}$ & $1 / 1$ & $1 / 1$ & - & $1 / 1$ & - \\
\hline & 191536 & A & G & $1 / 1$ & - & - & $1 / 1$ & $1 / 1$ \\
\hline & 192350 & $\mathrm{C}$ & $\mathrm{G}$ & - & $0 / 1$ & $1 / 1$ & $0 / 1$ & - \\
\hline & 221100 & $\mathrm{C}$ & G & $1 / 1$ & $1 / 1$ & $0 / 1$ & $1 / 1$ & $1 / 1$ \\
\hline & 221157 & $\mathrm{C}$ & $\mathrm{T}$ & $0 / 1$ & - & $0 / 1$ & $1 / 1$ & $0 / 1$ \\
\hline & 221172 & A & $\mathrm{C}$ & - & - & - & $1 / 1$ & $1 / 1$ \\
\hline & 244086 & $\mathrm{C}$ & G & $1 / 1$ & $1 / 1$ & $1 / 1$ & $1 / 1$ & $1 / 1$ \\
\hline & 254088 & $\mathrm{~T}$ & G & $1 / 1$ & - & $1 / 1$ & $1 / 1$ & $0 / 1$ \\
\hline & 254178 & $\mathrm{C}$ & A & $1 / 1$ & $1 / 1$ & $1 / 1$ & $1 / 1$ & $0 / 1$ \\
\hline & 280024 & A & G & - & $1 / 1$ & $1 / 1$ & $1 / 1$ & $1 / 1$ \\
\hline & 283040 & $\mathrm{C}$ & $\mathrm{T}$ & - & $1 / 1$ & $1 / 1$ & $1 / 1$ & $1 / 1$ \\
\hline & 341728 & A & $\mathrm{T}$ & $1 / 1$ & $1 / 1$ & $1 / 1$ & $1 / 1$ & $1 / 1$ \\
\hline & 354810 & A & $\mathrm{C}$ & $1 / 1$ & $1 / 1$ & $0 / 1$ & $0 / 1$ & $1 / 1$ \\
\hline & 354825 & A & $\mathrm{C}$ & $1 / 1$ & $1 / 1$ & - & - & - \\
\hline & 409749 & A & G & $1 / 1$ & $1 / 1$ & $1 / 1$ & - & $1 / 1$ \\
\hline & 460397 & $\mathrm{C}$ & $\mathrm{T}$ & $1 / 1$ & $1 / 1$ & $1 / 1$ & $1 / 1$ & $1 / 1$ \\
\hline & 460403 & $\mathrm{C}$ & $\mathrm{T}$ & $1 / 1$ & $1 / 1$ & $1 / 1$ & $1 / 1$ & $1 / 1$ \\
\hline & 460407 & A & $\mathrm{C}$ & $1 / 1$ & $1 / 1$ & $1 / 1$ & $1 / 1$ & $1 / 1$ \\
\hline & 463090 & $\mathrm{C}$ & $\mathrm{T}$ & - & - & $0 / 1$ & - & $1 / 1$ \\
\hline & 468704 & $\mathrm{C}$ & $\mathrm{T}$ & $1 / 1$ & $1 / 1$ & $1 / 1$ & $1 / 1$ & $1 / 1$ \\
\hline & 538448 & $\mathrm{~T}$ & A & $0 / 1$ & $1 / 1$ & $1 / 1$ & - & $0 / 1$ \\
\hline & 538453 & G & A & $0 / 1$ & $1 / 1$ & $1 / 1$ & $1 / 1$ & $0 / 1$ \\
\hline & 549422 & $\mathrm{~T}$ & $\mathrm{C}$ & $1 / 1$ & - & - & $1 / 1$ & $0 / 1$ \\
\hline & 666040 & A & G & $1 / 1$ & $0 / 1$ & $0 / 1$ & $1 / 1$ & $0 / 1$ \\
\hline & 729694 & A & G & $1 / 1$ & $1 / 1$ & $0 / 1$ & $0 / 1$ & $0 / 1$ \\
\hline & 729950 & G & A & $1 / 1$ & $1 / 1$ & $1 / 1$ & $0 / 1$ & $0 / 1$ \\
\hline & 733499 & G & $\mathrm{C}$ & $1 / 1$ & $0 / 1$ & $1 / 1$ & $1 / 1$ & - \\
\hline & 740135 & $\mathrm{~T}$ & $\mathrm{C}$ & $1 / 1$ & $1 / 1$ & $1 / 1$ & $0 / 1$ & $0 / 1$ \\
\hline & 743503 & $\mathrm{~T}$ & $\mathrm{C}$ & $1 / 1$ & - & - & - & - \\
\hline & 761539 & G & A & $1 / 1$ & $1 / 1$ & $0 / 1$ & $1 / 1$ & $0 / 1$ \\
\hline & 782432 & C & $\mathrm{T}$ & $1 / 1$ & $1 / 1$ & $1 / 1$ & $1 / 1$ & $0 / 1$ \\
\hline & 865966 & $\mathrm{~T}$ & A & $1 / 1$ & - & $0 / 1$ & $1 / 1$ & $1 / 1$ \\
\hline & 954985 & A & $\mathrm{C}$ & $0 / 1$ & - & $1 / 1$ & $1 / 1$ & $1 / 1$ \\
\hline & 955036 & A & $\mathrm{C}$ & $1 / 1$ & - & $1 / 1$ & $1 / 1$ & $1 / 1$ \\
\hline & 955067 & C & A & $0 / 1$ & $1 / 1$ & $1 / 1$ & $1 / 1$ & $1 / 1$ \\
\hline
\end{tabular}


(Continued)

\begin{tabular}{|c|c|c|c|c|c|c|c|c|}
\hline \multirow[t]{2}{*}{ Chromosome } & \multirow[t]{2}{*}{ Relative locus } & \multicolumn{2}{|c|}{$\begin{array}{c}\text { Silkie-Jinhu and } \\
\text { Silkie-Gushi shared } \\
\text { homozygous SNPs }\end{array}$} & \multicolumn{5}{|c|}{ Genotypes of the reference breeds } \\
\hline & & Ref & Alt & Cobb Broiler & White Leghorn & Beijing fatty & Wahui & White Recessive \\
\hline \multirow{11}{*}{$\operatorname{chrZ}$} & 967807 & $\mathrm{~A}$ & $\mathrm{C}$ & $1 / 1$ & - & $1 / 1$ & $1 / 1$ & $1 / 1$ \\
\hline & 996017 & G & $\mathrm{C}$ & - & - & - & - & - \\
\hline & 1088274 & $\mathrm{~T}$ & $\mathrm{C}$ & - & $1 / 1$ & $0 / 1$ & $1 / 1$ & $0 / 1$ \\
\hline & 1094160 & $\mathrm{C}$ & $\mathrm{T}$ & $1 / 1$ & $1 / 1$ & $1 / 1$ & $1 / 1$ & $0 / 1$ \\
\hline & 1233167 & $\mathrm{~T}$ & $\mathrm{C}$ & $1 / 1$ & $1 / 1$ & $1 / 1$ & - & - \\
\hline & 1255948 & $\mathrm{~T}$ & A & $1 / 1$ & - & $0 / 1$ & $1 / 1$ & $0 / 1$ \\
\hline & 1255959 & $\mathrm{C}$ & $\mathrm{T}$ & $1 / 1$ & - & $1 / 1$ & $0 / 1$ & $0 / 1$ \\
\hline & 1255999 & A & G & $1 / 1$ & $1 / 1$ & $1 / 1$ & $1 / 1$ & $0 / 1$ \\
\hline & 1256029 & A & $\mathrm{T}$ & $1 / 1$ & $1 / 1$ & - & - & $0 / 1$ \\
\hline & 1363748 & G & A & $1 / 1$ & - & $0 / 1$ & $0 / 1$ & $0 / 1$ \\
\hline & 1400989 & $\mathrm{C}$ & G & - & $1 / 1$ & - & $1 / 1$ & - \\
\hline
\end{tabular}

Note: 1/1 denotes homozygous minor allele; 0/1 denotes heterozygous minor allele; - denotes homozygous reference allele.

heterozygote in the Silkie, Jinhu Silkie and Gushi chickens, which is inconsistent with the theoretically expected inheritance pattern. We also performed an InDel analysis but after comparison with the reference reed sequences, the initial 10 candidate InDels were not present ( Table 3).

Table 2 Sequencing data without consideration of the genotype

\begin{tabular}{|c|c|c|c|c|c|c|c|c|c|c|c|}
\hline & \multirow{2}{*}{$\begin{array}{l}\text { Relative } \\
\text { locus } \\
\text { [position] }\end{array}$} & \multicolumn{2}{|c|}{$\begin{array}{c}\text { Silkie-Jinhu and Silkie- } \\
\text { Gushi shared SNPs }\end{array}$} & \multicolumn{3}{|c|}{ Genotype } & \multicolumn{5}{|c|}{ Genotypes of the reference breeds } \\
\hline & & Ref & Alt & Jinhu & Gushi & Silkie & $\begin{array}{l}\text { Cobb } \\
\text { Broiler }\end{array}$ & $\begin{array}{l}\text { White } \\
\text { Leghorn }\end{array}$ & Beijing fatty & Wahui & $\begin{array}{c}\text { White } \\
\text { Recessive }\end{array}$ \\
\hline \multirow{3}{*}{$\operatorname{chrZ}$} & 103096 & A & $\mathrm{G}$ & $0 / 1$ & $0 / 1$ & $0 / 1$ & - & - & - & - & - \\
\hline & 154216 & $\mathrm{~T}$ & $\mathrm{C}$ & $1 / 1$ & $0 / 1$ & $0 / 1$ & - & - & - & - & - \\
\hline & 1023728 & A & $\mathrm{T}$ & $0 / 1$ & $0 / 1$ & $0 / 1$ & - & - & - & - & - \\
\hline
\end{tabular}

Note:1/1 denotes homozygous minor allele; 0/1 denotes heterozygous minor allele; - denotes homozygous reference allele.

Table 3 InDel sequences

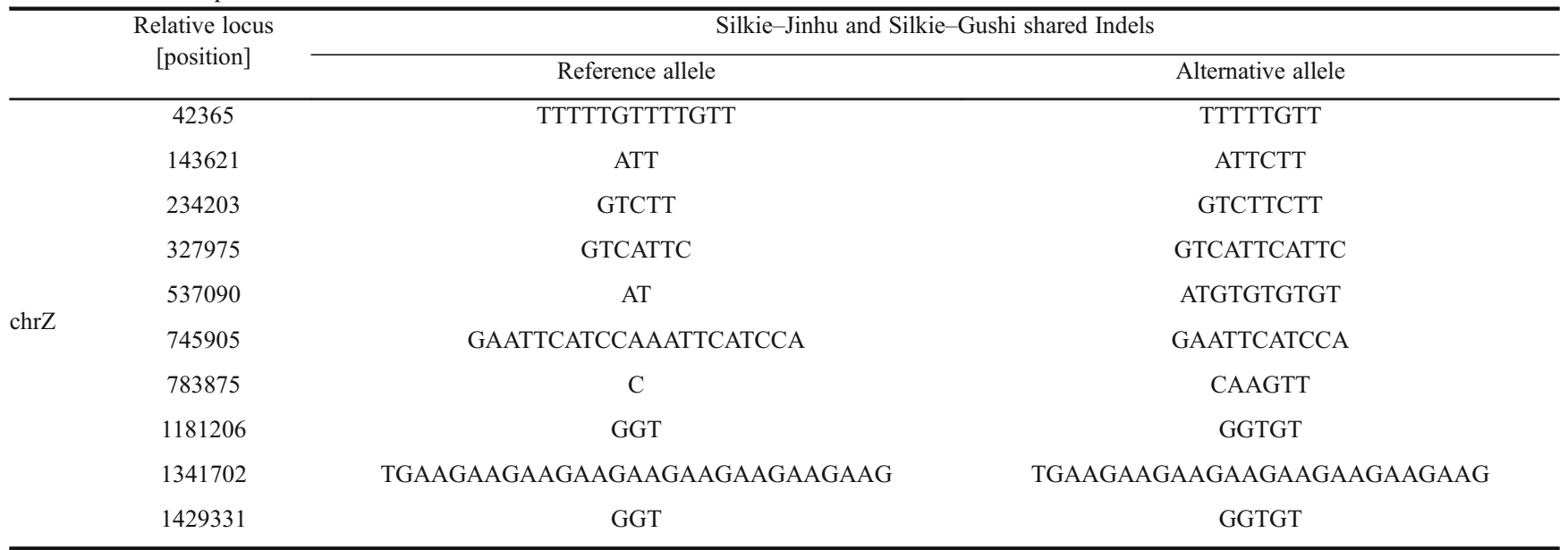




\section{Conclusions}

$I d$ has an epistatic effect on $F m$, pigmentation of the shank dermis in chickens occurs with $i d^{+}$and $F m$ with $i d^{+}$causes hyperpigmentation in the Silkie chicken [7,8]. Given that $i d^{+}$is homozygous in Silkie chicken, we speculated that the gene corresponding to $I D$ in our targeted region would be expressed at a higher level in Silkie than in White Leghorn chickens. ID should be expressed during early embryo development because melanocytes are present by day 3 of embryo development in Silkie chickens and can be observed by eye from day 8 . Considering the functions of the proteins encoded by the ten genes in our targeted chrZ region and their expression levels during embryonic development, it seems possible that MTAP would be $I D$.

To attempt to identify the causative mutation we performed a target DNA capture and sequencing analysis based on genotype and without consideration of the genotype. We also performed an InDel analysis. However, given the theory behind target DNA capture and the complex structure of chrZ, the causal mutation could not be unambiguously identified. Further work is necessary to identify this mutation.

Acknowledgements We are grateful to the Guangzhou Academy of Agricultural Sciences, Jiangsu Institute of Poultry Sciences and their members who provided samples, Dr. Zhe Yang (Agilent Technologies) for assistance with the array design, BerryGenomics Company for performing IlluminaSolexa sequencing and Dr. Yujun Zhang (Bioyong Tech) for assistance with data analysis. This work was funded by the National Natural Science Foundation of China (U0831003) and the National Advanced Technology Research and Development Program of China (2011AA100301).

Supplementary material The online version of this article at http://dx.doi. org/(doi:10.15302/J-FASE-2014018) contains supplementary material (Appendix A and Appendix B).

Compliance with ethics guidelines Ming Tian, Rui Hao, Suyun Fang, Yanqiang Wang, Xiaorong Gu, Chungang Feng, Xiaoxiang Hu and Ning Li declare that they have no conflict of interest or financial conflicts to disclose.

All applicable institutional and national guidelines for the care and use of animals were followed.

\section{References}

1. Rosengren Pielberg G, Golovko A, Sundström E, Curik I, Lennartsson J, Seltenhammer M H, Druml T, Binns M, Fitzsimmons C, Lindgren G, Sandberg K, Baumung R, Vetterlein M, Strömberg S, Grabherr M, Wade C, Lindblad-Toh K, Pontén F, Heldin C H, Sölkner J, Andersson L. A cis-acting regulatory mutation causes premature hair graying and susceptibility to melanoma in the horse. Nature Genetics, 2008, 40(8): 1004-1009

2. Eizirik E, David V A, Buckley-Beason V, Roelke M E, Schäffer A A, Hannah S S, Narfström K, O’Brien S J, Menotti-Raymond M. Defining and mapping mammalian coat pattern genes: multiple genomic regions implicated in domestic cat stripes and spots. Genetics, 2010, 184(1): 267-275

3. Alizadeh A, Hong L Z, Kaelin C B, Raudsepp T, Manuel H, Barsh G
S. Genetics of Sex-linked yellow in the Syrian hamster. Genetics, 2009, 181(4): 1427-1436

4. Gunnarsson U, Hellström A R, Tixier-Boichard M, Minvielle F, Bed'hom B, Ito S, Jensen P, Rattink A, Vereijken A, Andersson L. Mutations in SLC45A2 cause plumage color variation in chicken and Japanese quail. Genetics, 2007, 175(2): 867-877

5. Eriksson J, Larson G, Gunnarsson U, Bed'hom B, Tixier-Boichard M, Strömstedt L, Wright D, Jungerius A, Vereijken A, Randi E, Jensen P, Andersson L. Identification of the yellow skin gene reveals a hybrid origin of the domestic chicken. PLOS Genetics, 2008, 4(2): e1000010

6. Dorshorst B, Okimoto R, Ashwell C. Genomic regions associated with dermal hyperpigmentation, polydactyly and other morphological traits in the Silkie chicken. Journal of Heredity, 2010, 101(3): 339-350

7. Smyth J R Jr. Genetics of plumage. Skin and eye pigmentation in chickens. Crawford RD, ed. Amsterdam. 1990

8. Hutt F B. Genetics of the fowl. McGraw-Hill. 1949

9. Le D. M. N. The Neural Crest. Cambridge University. 1982

10. Erickson C A, Reedy M V. Neural crest development: the interplay between morphogenesis and cell differentiation. Current Topics in Developmental Biology, 1998, 40: 177-209

11. Erickson C A, Goins T L. Avian neural crest cells can migrate in the dorsolateral path only if they are specified as melanocytes. Development, 1995, 121(3): 915-924

12. Reedy M V, Faraco C D, Erickson C A. Specification and migration of melanoblasts at the vagal level and in hyperpigmented Silkie chickens. Developmental Dynamics, 1998, 213(4): 476-485

13. Hallet M M, Ferrand R. Quail melanoblast migration in two breeds of fowl and in their hybrids: evidence for a dominant genic control of the mesodermal pigment cell pattern through the tissue environment. Journal of Experimental Zoology, 1984, 230(2): 229-238

14. Dunn L, Jull M. On the inheritance of some characters op the silky fowl. Journal of Genetics, 1927, 19: 27-63

15. Bateson W, Punnett R. The inheritance of the peculiar pigmentation of the silky fowl. Journal of Genetics, 1911, 1: 185-203

16. Bitgood J J. Linear relationship of the loci for barring, dermal melanin inhibitor, and recessive white skin on the chicken $\mathrm{Z}$ chromosome. Poulty Science, 1988, 67(4): 530-533

17. Dorshorst B J, Ashwell C M. Genetic mapping of the sex-linked barring gene in the chicken. Poulty Science, 2009, 88(9): 1811-1817

18. Groenen M A, Cheng H H, Bumstead N, Benkel B F, Briles W E, Burke T, Burt D W, Crittenden L B, Dodgson J, Hillel J, Lamont S, de Leon AP, Soller M, Takahashi H, Vignal A. A consensus linkage map of the chicken genome. Genome Research, 2000, 10(1): 137147

19. Levin I, Crittenden L B, Dodgson J B. Genetic map of the chicken Z chromosome using random amplified polymorphic DNA (RAPD) markers. Genomics, 1993, 16(1): 224-230

20. Wright D, Kerje S, Lundström K, Babol J, Schütz K, Jensen P, Andersson L. Quantitative trait loci analysis of egg and meat production traits in a red junglefowl $\times$ White Leghorn cross. Animal Genetics, 2006, 37(6): 529-534

21. Dorshorst B, Okimoto R, Ashwell C. Genomic regions associated with dermal hyperpigmentation, polydactyly and other morpholo- 
gical traits in the Silkie chicken. Journal of Heredity, 2010, 101(3): 339-350

22. Bellott D W, Skaletsky H, Pyntikova T, Mardis E R, Graves T, Kremitzki C, Brown L G, Rozen S, Warren W C, Wilson R K, Page D C. Convergent evolution of chicken $\mathrm{Z}$ and human $\mathrm{X}$ chromosomes by expansion and gene acquisition. Nature, 2010, 466(7306): 612-616

23. Been J V, Bok L A, Willemsen M A, Struys E A, Jakobs C. Mutations in the ALDH7A1 gene cause pyridoxine-dependent seizures. Arquivos de Neuro-Psiquiatria, 2008, 66(2-A): 288-289

24. Strunnikova N V, Maminishkis A, Barb J J, Wang F, Zhi C, Sergeev Y, Chen W, Edwards A O, Stambolian D, Abecasis G, Swaroop A, Munson P J, Miller S S. Transcriptome analysis and molecular signature of human retinal pigment epithelium. Human Molecular Genetics, 2010, 19(12): 2468-2486

25. Lee R, Chang S Y, Trinh H, Tu Y, White A C, Davies B S, Bergo M O, Fong L G, Lowry W E, Young S G. Genetic studies on the functional relevance of the protein prenyltransferases in skin keratinocytes. Human Molecular Genetics, 2010, 19(8): 1603-1617

26. Miyajima N, Maruyama S, Nonomura K, Hatakeyama S. TRIM36 interacts with the kinetochore protein CENP-H and delays cell cycle progression. Biochemical and Biophysical Research Communications, 2009, 381(3): 383-387

27. Haecker A, Qi D, Lilja T, Moussian B, Andrioli L P, Luschnig S, Mannervik M. Drosophila brakeless interacts with atrophin and is required for tailless-mediated transcriptional repression in early embryos. PLoS Biology, 2007, 5(6): e145

28. Appeddu P A, Shur B D. Control of stable lamellipodia formation by expression of cell surface beta 1,4-galactosyltransferase cytoplasmic domains. Journal of Cell Science, 1994, 107(Pt 9): 2535-2545

29. Reedy M V, Faraco C D, Erickson C A. Specification and migration of melanoblasts at the vagal level and in hyperpigmented Silkie chickens. Developmental Dynamics, 1998, 213(4): 476-485

30. Thomas A J, Erickson C A. The making of a melanocyte: the specification of melanoblasts from the neural crest. Pigment Cell \& Melanoma Research, 2008, 21(6): 598-610

31. Ventura-Holman T, Lu D, Si X, Izevbigie E B, Maher J F. The Fem 1c genes: conserved members of the Fem 1 gene family in vertebrates. Gene, 2003, 314: 133-139

32. Krakow D, Sebald E, King L M, Cohn D H. Identification of human FEM1A, the ortholog of a C. elegans sex-differentiation gene. Gene, 2001, 279(2): 213-219

33. Rose A E, Poliseno L, Wang J, Clark M, Pearlman A, Wang G, Vega Y Saenz de Miera E C, Medicherla R, Christos P J, Shapiro R, Pavlick A, Darvishian F, Zavadil J, Polsky D, Hernando E, Ostrer H, Osman I. Integrative genomics identifies molecular alterations that challenge the linear model of melanoma progression. Cancer Research, 2011, 71(7): 2561-2571

34. Holdt L M, Sass K, Gäbel G, Bergert H, Thiery J, Teupser D. Expression of Chr9p21 genes $C D K N_{2} B\left(p 15^{I N K 4 b}\right), C D K N_{2} A$ $\left(p 16^{I N K 4 a}, p 14^{A R F}\right)$ and MTAP in human atherosclerotic plaque. Atherosclerosis, 2011, 214(2): 264-270 